\title{
Corporate Social Responsibilities and Firm Performance
}

\author{
Joshua Adeyemi Ogunjimi \\ Department of Economics, University of Ibadan, Nigeria. \\ Email.joshuaogunjimi@gmail.com Tel:+2348064795124
}

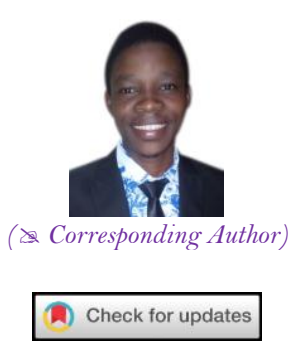

\section{Abstract}

This study evaluated the impact of corporate social responsibility on firm performance using MTN Service centres in Ibadan, Nigeria as case study. Tables and simple percentages were used for the analysis of the data collected through the administration of questionnaires while the correlation coefficient and analysis of variance were employed as the analytical tool for this study. The results showed that all the MTN service centres in Ibadan carry out CSR albeit with few challenges. It was also found that several benefits accrue to MTN in Ibadan as a result of carrying out CSR activities. Furthermore, the correlation coefficient revealed a strong positive relationship between MTN's Corporate Social Responsibility (CSR) and her organizational performance in Ibadan such that an increase in CSR activities would improve its performance. Similarly, the regression result showed a significant positive relationship between CSR and firm performance which indicates that CSR influences the performance of MTN service centres in Ibadan. Therefore, this study concludes that CSR is a determinant of firm performance. Based on these findings, this study recommends that the management of MTN Nigeria endeavour to engage in more CSR activities to meet the peculiar needs of their immediate environment since it has a way of improving their performance as well as profitability.

Keywords: CSR, Firm Performance, MTN, Ibadan, Correlation, Regression

JEL Classification:C12; D24; G30; L25.

\section{Introduction}

Corporate Social Responsibilities (CSR) continues to be a topical issue at different local and international forums given its inherent benefits to the society, firms, government and the economy at large. CSR is a broad set of obligatory programmes, practices and policies incorporated into the supply chains, business operations and decision-making processes of a firm as a form to contribution to or appreciation of their host community or government. It involves taking corporate and social responsibilities of their past and current business operations as well as their future impacts particularly on the host community (Adeyanju, 2012; Mirfazli, 2008). On the other hand, the scope of CSR has also been a subject of debate in the literature such that whereas some authors believed that CSR should be limited to only the stakeholders of the company (Secchi, 2007; Smith, 2003) others alluded that it should include the society at large (Brown \& Dacin, 1997; Kotler \& Lee, 2005; Lee, 2008).

The evolution of CSR has instigated a paradigm shift of firms from their philosophy of only maximizing profit to solving social problems facing their host community or government (Secchi, 2007). This has made charting a new course of action as regards performing CSR vital for firms as it has become a prerequisite for improved firm performance (Korkchi \& Rombaut, 2007). The proponents of CSR argued that it is laced with numerous benefits including: increasing customer loyalty, improved public image, better access to financial credits, enhanced brand name, greater trust and confidence of stakeholders, motivated community, and safer or healthier workplace, among others (Diffey, 2007; Elizaveta, 2010; Mirfazli, 2008; Tuodolo, 2009). Specifically,Tapang and Bassey (2017) argued that CSR-performing firms tend to enjoy better long run corporate performance mostly stemming from the support, kindness, peace and tranquillity their operating environment affords them. However, the degree or volume of CSR varies from company to company and community to community. The size and degree of CSR are often determined by the legal framework, firm's product or service type (environmentally detrimental product or service firms are likely to be required to carry out more CSR), business sector, firm or company size, economic situations in the host community and geographical location, among other (Adeyanju, 2012). Given the increasing inability of the government (especially those in developing economies) to single-handedly tackle the economic and environmental problems of its citizens, CSR has been identified as a viable option through which the private sector can help partner with the government to shoulder the responsibilities of growth and development of the economy. Accordingly, the burgeoning socio-economic needs of Nigeria are so numerous that corporate organizations must intervene to help salvage the economic situations in Nigeria. Interestingly, CSR remains one of the strategic ways through which this could be attained. Many telecommunication companies in Nigeria have been exploring this 
channel in a bid to have competitive edge over their competitors, expand their customer base and boost their profitability. However, most of the CSR activities of these telecommunication firms are adjudged to be with ulterior motives rather than from philanthropic and ethical perspectives (Amposah-Tawiah \& Dartey-Baah, 2011).

Unfortunately, the concept of CSR has not been fully integrated by the firms of various sectors of the Nigerian economy. The argument is that there exists a systematic approach in allocating costs, whether for investment or societal well-being (Kanwal, Khanam, Nasreen, \& Hameed, 2013). They rather see their involvement in CSR as the function of the culture of the firm, size and stakeholders demand. It is pertinent to note that in developing countries like Nigeria where consumer education awareness is low, with little or no organized pressure group put in place, there is difficulty in the demand of full implementation of the CSR by society or institutions. Therefore, a good number of managers of these firms in Nigeria, including Mobile Telecommunication of Nigeria (MTN), tend to demonstrate poor attitude towards CSR. Hence, CSR in developing countries including Nigeria is still at low ebb despite the intense campaigns for facilitating corporate social programmes for tackling various economic maladies in the society. There are a number of studies on the CSR-firm performance nexus in the literature for several countries of the world (Boafo \& Kokuma, 2016; Elizaveta, 2010; Freeman \& Phillips, 2002; Nguyen, Hoang, \& Luu, 2019; Tsoutsoura, 2004; Wael, 2014) including CSR in the Nigerian manufacturing sector (Nnamani, Onyekwelu, \& Ugwu, 2017; Olaroyeke \& Nasieku, 2015) and services sector (Adebisi \& Akinmadelo, 2014; Nsikan, Umoh, \& Bariate, 2015; Tapang \& Bassey, 2017). However, studies examining the CSR activities and the performance of a service firm in Ibadan are particularly rare. Studies of this nature are important to effectively disentangle the variation in CSR activities across different geographical locations in Nigeria so as to aid plausible comparisons. Thus, this study seeks to fill this gap in the literature by exploring the relationship between CSR and MTN performance in Ibadan, Oyo State, Nigeria. Specifically, this study will examine the CSR activities carried out by MTN, Ibadan; examine the extent to which MTN carries out CSR and its benefits; evaluate the problems MTN encounters in the practice of CSR; and assess whether CSR enhances the performance of MTN. Gbam and Dedi (2017) carried out a similar study for Plateau state and Ogunsanwo and Ajayi (2018) did same for Ado-Ekiti.

Following this introductory section, the rest of this paper is organized as follows: section two presents the review of relevant literature, section three discusses the research methodology adopted in this study, section four interprets the empirical findings while section five concludes this study.

\section{Literature Review}

There are various views in the literature with regards to the impact of CSR on firm performance and societal welfare. Freeman and Phillips (2002) postulated that CSR is an action a company decides to take that will adequately affect identifiable social stakeholders' welfare. However, Tsoutsoura (2004) averred that the management and corporate companies should step up to implement policies and business practices beyond the minimum legal requirement and positively affect the welfare of its key stakeholders. Elizaveta (2010) alluded that CSR-practising firms tend to attract great customers, shareholders and the best employees as against firms who do not perform CSR. Moreover, Mujahid and Abdullah (2014) investigated the effects of CSR on firm's financial performance and shareholders' wealth of 20 firms in the Pakistani economy. Their results showed that CSR exerts a positive influence on the financial performance and shareholders wealth of the firms. Similarly, Wael (2014) administered questionnaires and employed the descriptive statistical method to evaluate the impact of CSR on the profitability of the Orange Telecommunication Company in Jordan. The result suggests that CSR has a positive impact on firm's profitability. In a similar study on Vodafone Ghana Limited, Boafo and Kokuma (2016) showed that CSR has an ample positive effect on finances, brand differentiation, reputation and employees' commitment and of the company. In a study on MTN Telecommunication Company in Nigeria, Adebisi and Akinmadelo (2014) found that good ethical, society-focused and environmental CSR affects the performance of the mobile service provider positively. On the other hand, Olaroyeke and Nasieku (2015) examined the impact of CSR on the performance of fifteen manufacturing firms listed on the Nigerian Stock Exchange Market. Using descriptive statistics to analyse the collected data, their empirical result indicated that CSR impacts the performance of these firms positively and that these firms engage in CSR not just for profit-making but also for promoting their brand name, improving their corporate image and enhancing their competitive advantage.

Nsikan et al. (2015) used the survey method and random sampling technique to collect data with which to evaluate the nexus between CSR and competitiveness of mobile telecommunication companies. Their finding showed that CSR enhances competitive advantage of firms. Using the exploratory qualitative approach, Nguyen et al. (2019) examined CSR with special attention on the opportunities and innovations experienced within four Vietnamese multinational subsidiaries. The results showed that CSR activities triggered new business innovations and opportunities. Moreover, Ohiokha, Odion, and Akhalumeh (2016) sampled twenty-nine firms for the period between 2005 and 2010 to evaluate the nexus between CSR and corporate financial performance in Nigeria. The panel regression results showed that CSR has a negligible effect on the firm's financial performance. In the same vein, Gbam and Dedi (2017)analysed the impacts of CSR on telecommunication industry in Plateau State, Nigeria. The chi-square result revealed that CSR exert a substantial impact on social progress. More so, Akinleye and Adedayo (2017) randomly selected five Nigerian multinational companies and collected their 5-year financial reports (2010-2014) to analyse the impact of CSR on their profitability level. They found a weak negative relationship between CSR and company's profit as well as a unidirectional causality running from CSR to company's profitability. On the other hand, Oladimeji, Adebayo, and Ogunshola (2017) evaluated the impact of CSR on customers' loyalty and retention. Using the correlation and regression analysis, their result revealed that CSR enhances customers' loyalty and retention. However, Nnamani et al. (2017) analysed the impact of sustainability accounting on the financial performance of selected manufacturing firms in the Nigerian Brewing industry with the result showing that sustainability reporting exerts a positive impact on the firms' financial performance. Besides, Tapang and Bassey (2017) assessed the impact of CSR on stakeholder's perception of telecommunication companies in Nigeria. The multiple regression result showed that economic, legal, ethical and discretional expectation of CRS performance impact stakeholder's perception significantly. Ogunsanwo and Ajayi (2018) assess the impact of CSR on the performance of MTN Nigeria and found a significant relationship between economic, legal and philanthropic expectations of CSR and firm performance but an insignificant relationship between ethical expectation and firm 
performance. The foregoing shows that there is no consensus on the impact of CSR on firm performance due to differences in methodological approaches, measurement issues, firm type, business sectors, and data sources, among others. As a matter of fact, the studies that found a positive impact of CSR on firm performance have different opinions on the nature of relationship and the magnitude of impact. More so, studies of this nature have not been carried out for MTN Ibadan, Nigeria. This shows that it is needful to examine this relationship so as to formulate and implement appropriate CSR policies for the good of the host community and country at large.

\section{Research Methodology}

\subsection{Research Design}

This study assesses the impact of corporate social responsibility on the performance of MTN, Ibadan through the use of a descriptive survey design (questionnaire). Survey method is considered appropriate because it helps to assess the knowledge and attitude of people at a particular period. The choice of this research design (questionnaire) lies in its ability to facilitate adequate data collection, aid easy administration and enhance easy documentation.

\subsection{Sample Size and Sampling Technique}

The sample size comprises all the fourteen (14) MTN service centres scattered across the whole of Ibadan thus, one questionnaire each is administered to the fourteen (14) managers, twenty (20) customer care representatives and sixteen (16) attendants of these service centres. These members of staffs are selected since they are better placed to answer the question in the questionnaire as they would give accurate and reliable information with which the analysis of this study will be carried out and recommendations made to improve both CSR and performance of MTN in Nigeria. Hence, this study employs the purposive non-probability sampling techniques because there is no ambiguity about the target population to whom the survey instrument (questionnaire) will be administered.

\subsection{Method of Data Collection}

This study sourced for both primary and secondary data. Primary data is collected through the administration of questionnaire which contains both open and close ended questions on CSR and performance of MTN in Ibadan. On the other hand, the secondary data used for this study are source from the website of the MTN Nigeria.

\subsection{Methods of Data Analysis}

The Statistical Package for Social Sciences (SPSS) software was used to collate and analyse the collected data of this study. The collected data were collated and analysed in tables, simple percentages and the hypotheses was tested using Correlation coefficient and analysis of variance (ANOVA) to investigate impact of CSR on organizational performance in MTN, Ibadan.

\section{Empirical Analysis}

\subsection{Socio-Economic Characteristics of Respondents}

Table 1 presents the socio-economic characteristics of respondents of this study. It shows that $10(20 \%)$ of the respondents are selected from the Ibadan Service Centre which is the headquarters of MTN Nigeria in Ibadan. 5 $(10 \%)$ of the respondents are chosen from Cocoa Mall Connect Lite, $3(6 \%)$ of the respondents are selected from each of Ibadan2/Bodija Connect Store, Ibadan Connect Store, Iwo Road, Mokola Centre, Idi Ape Centre, Total Garden Centre, Eleyele Centre, Akobo Connect Point, Sango Connect Point, Iyaganku Connect Point, New Ife Road Connect Point and Ibadan2 Service Centre, Agodi Gate, while only 2 (4\%) of the respondents was selected from University of Ibadan (UI) Centre because it has just two (2) staffs. Further, distribution of the position held by MTN shows that $14(28 \%)$ of the respondents are managers, $20(40 \%)$ are customer care representatives and 16 $(32 \%)$ are attendants. Furthermore, $30(60 \%)$ of the respondents are males and $20(40 \%)$ are females. This indicates that MTN has more male staffs than female. In addition, the age distribution of the respondents reveals that 5 $(10 \%)$ of the respondents are between the age of 18 and 55; 15 (30\%) falls in the 26-30 age bracket; $10(20 \%)$ falls between the age of 31 and 35; and $20(40 \%)$ are 36 years and above. The age bracket that has the least percentage among the respondents is the 18-25. The addition of the percentage of age group 18-25, 26-30 and 31-35, totalling $60 \%$ suggests that the MTN has the human resources in terms of the working class or the active labour force that is capable of generating enough resources and thereby driving development in the company. Moreover, the distribution of the marital status of the respondents in MTN shows that 15 respondents which represents $30 \%$ of the respondents are single while the remaining $35(70 \%)$ of the respondents are married. This depicts that most of MTN staffs are married. Table 1 also shows the religion of the respondents. It reveals that $30(60 \%)$ of the respondents are Christians while $18(36 \%)$ are Muslims, and the remaining $2(4 \%)$ are Traditionalists. This suggests that there is peaceful co-existence among the staffs and their right to willingly express their freedom of worship is not being denied. It also shows that 36 respondents representing $(72 \%)$ of the total respondent earn less than \#50,000 per month while only $28 \%$ of the respondents earn between \#101,000 and \#150,000 per month.

\subsection{Presentation and Interpretation of Result}

\subsubsection{Corporate Social Responsibility Programs of MTN in Ibadan}

The report from the website of MTN Nigeria reports that all the MTN service centres in Ibadan engage in CSR activities. MTN Foundation, incorporated in 2004, is the body charged with the responsibility of driving MTN's various CSR initiatives. The CSR programs they undertake are: ICT and Business Skill training, provision of transformers for electrification, drilling of boreholes for potable water, provisions of food and capital items to orphanages, provision of digital libraries in universities, refurbishment of Adeoyo Maternity Teaching Hospital, organizing independent living programmes for people living with disabilities, provision of basic teaching and learning materials, the MTN Rural Telephone Project (RTP) and MTN Foundation Schools-Connect project, 
among otherssee Table 2. The beneficiaries of the CSR programs are the customers, host communities, general public, employees and the government.

Table-1.Socio-economic characteristics of respondents.

\begin{tabular}{|c|c|c|c|}
\hline S/No & Socio-Economic Characteristics Of Respondents & Frequency & Percentage \\
\hline \multirow[t]{15}{*}{1.} & Name and Address of Service Centre & & \\
\hline & Ibadan Service Centre, Ring Road & 10 & 20 \\
\hline & Cocoa Mall Connect Lite, Dugbe & 5 & 10 \\
\hline & Ibadan2/Bodija Connect Store, Bodija & 3 & 6 \\
\hline & Ibadan Connect Store, Iwo Road & 3 & 6 \\
\hline & University of Ibadan (UI) Centre & 2 & 4 \\
\hline & Mokola Centre & 3 & 6 \\
\hline & Idi Ape Centre & 3 & 6 \\
\hline & Total Garden Centre & 3 & 6 \\
\hline & Eleyele Centre & 3 & 6 \\
\hline & Akobo Connect Point & 3 & 6 \\
\hline & Sango Connect Point & 3 & 6 \\
\hline & Iyaganku Connect Point & 3 & 6 \\
\hline & New Ife Road Connect Point & 3 & 6 \\
\hline & Ibadan2 Service Centre & 3 & 6 \\
\hline \multirow[t]{4}{*}{2.} & Position Held in the Service Centre & & \\
\hline & Manager & 14 & 28 \\
\hline & Customer Care Representatives & 20 & 40 \\
\hline & Attendants & 16 & 32 \\
\hline \multirow[t]{3}{*}{3.} & Sex & & \\
\hline & Male & 30 & 60 \\
\hline & Female & 20 & 40 \\
\hline \multirow[t]{5}{*}{4.} & Age & & \\
\hline & $18-25$ & 5 & 10 \\
\hline & $26-30$ & 15 & 30 \\
\hline & $31-35$ & 10 & 20 \\
\hline & 36 and above & 20 & 40 \\
\hline \multirow[t]{5}{*}{5.} & Marital Status & & \\
\hline & Single & 15 & 30 \\
\hline & Married & 35 & 70 \\
\hline & Widowed & 0 & 0 \\
\hline & Separated/Divorced & 0 & 0 \\
\hline \multirow[t]{5}{*}{6.} & Religious Affiliation & & \\
\hline & Christianity & 30 & 60 \\
\hline & Islam & 18 & 36 \\
\hline & African Traditional Religion & 2 & 4 \\
\hline & Others & 0 & $\mathrm{O}$ \\
\hline \multirow[t]{5}{*}{7.} & Income level per month & & \\
\hline & Below \#50,000 & 36 & 72 \\
\hline & $\# 51,000-\# 100,000$ & 0 & 0 \\
\hline & $\# 101,000-\# 150,000$ & 14 & 28 \\
\hline & Above \#150,000 & 0 & 0 \\
\hline
\end{tabular}

Table-2. Corporate social responsibility programs of MTN in Ibadan

\begin{tabular}{l|l}
\hline S/No & CSR Programs And Beneficiaries \\
\hline 1. & The main CSR programs undertaken by MTN, Ibadan \\
\hline i. & ICT and Business Skill Training \\
\hline ii. & Provision of Transformer \\
\hline iii. & Drilling of Borehole \\
\hline iv. & Provisions of food and capital items to Orphanages \\
\hline v. & Digital Libraries in Universities \\
\hline vi. & Refurbishment of Adeoyo Maternity Teaching Hospital \\
\hline vii. & Independent Living Programmes for People Living with Disabilities \\
\hline viii. & MTN Foundation Schools-Connect project \\
\hline ix. & Provision of basic teaching and learning materials \\
\hline x. & The MTNF Rural Telephone Project (RTP) \\
\hline 2. & Beneficiaries of MTN Ibadan's CSR programs \\
\hline i. & Customers \\
\hline ii. & Host Communities \\
\hline iii. & General Public \\
\hline iv. & Employees \\
\hline v. & Government \\
\hline Source: Fieldwork (2020).
\end{tabular}

\subsubsection{Benefits/Effects of Practising CSR}

Table 3 presents the responses of the respondents on the benefits that accrue to MTN through practising CSR. Table 3 shows that $70 \%$ and $30 \%$ of the respondents strongly agreed and agreed respectively that CSR improves corporate reputation, image and identity. This indicates that CSR actually improves corporate reputation, image and identity. On whether CSR enhance profit maximization, 90\% agreed while only $10 \%$ disagreed thus indicating that CSR enhances profit maximization. Furthermore, with mean value and standard deviation of 1.94 and 0.91 respectively, the respondents showed that CSR helps to reduce operational costs. In addition, $76 \%$ and $24 \%$ of the respondents strongly agreed and agreed respectively to the fact that CSR enhances company's ability to attract talent and retain staff and that CSR raises public interest in the activities of the company. $56 \%$ and $46 \%$ of the respondents also strongly agreed and agreed respectively that CSR enhances market and financial performance. 
Also, $74 \%$ and $26 \%$ of the respondents strongly agreed and agreed respectively that CSR raises investors confidence and customers' loyalty. Furthermore, with a mean value and standard deviation of 1.18 and 0.38 respectively, the respondents opined that CSR improves public goodwill towards the company. However, whereas $50 \%$ and $30 \%$ of the respondents strongly agreed and agreed respectively that CSR facilitates the overall performance of the company, $10 \%$ disagreed. Moreover, $80 \%$ and $20 \%$ of the respondents strongly agreed and agreed respectively that CSR leads to improved sales and increased profits. Also, the assertion that CSR aids organizational growth was strongly agreed and agreed on by $70 \%$ and $30 \%$ respectively. Also, whereas $40 \%$ and $36 \%$ of the respondents strongly agreed and agreed respectively that CSR attracts positive media attention, $4 \%$ are undecided, $16 \%$ disagreed and $4 \%$ strongly disagreed. Additionally, whereas $62 \%$ and $34 \%$ of the respondents strongly agreed and agreed respectively that CSR increases our market share, $4 \%$ are undecided. Likewise, $34 \%$, $46 \%, 6 \%, 10 \%$ and $4 \%$ of the respondents strongly agreed, agreed, were undecided, disagreed and strongly disagreed respectively that CSR makes access to finance easier. Similarly, 24\%, 38\%, $12 \%, 18 \%$ and $8 \%$ of the respondents strongly agreed, agreed, were undecided, disagreed and strongly disagreed respectively that CSR eases/reduces regulatory burden.

Table-3.Benefits/effects of practisingCSR

\begin{tabular}{|c|c|c|c|c|c|c|c|c|}
\hline No. & Benefits/Effects of Practising CSR & SA & $\mathbf{A}$ & $\mathbf{U}$ & $\mathbf{D}$ & SD & Mean & Std. Dev. \\
\hline 1. & $\begin{array}{l}\text { It improves corporate reputation, image } \\
\text { and identity }\end{array}$ & $35(70 \%)$ & $15(30 \%)$ & $\mathrm{O}(0 \%)$ & $\mathrm{O}(0 \%)$ & $\mathrm{O}(\mathrm{O} \%)$ & 1.30 & 0.46 \\
\hline 2. & It enhances profit maximization & $26(52 \%)$ & $14(28 \%)$ & $0(0 \%)$ & $8(16 \%)$ & $2(4 \%)$ & 1.92 & 1.24 \\
\hline 3. & It helps in reduction in operational cost & $18(36 \%)$ & $21(42 \%)$ & $\mathrm{O}(\mathrm{O} \%)$ & $7(14 \%)$ & $4(8 \%)$ & 1.94 & 0.91 \\
\hline 4. & $\begin{array}{l}\text { It enhances company's ability to attract } \\
\text { talent and retain staff }\end{array}$ & $38(76 \%)$ & $12(24 \%)$ & $\mathrm{O}(0 \%)$ & $\mathrm{O}(0 \%)$ & $\mathrm{O}(0 \%)$ & 1.24 & 0.43 \\
\hline 5. & $\begin{array}{l}\text { It enhances market and financial } \\
\text { performance }\end{array}$ & $28(56 \%)$ & $22(44 \%)$ & $\mathrm{O}(\mathrm{O} \%)$ & $\mathrm{O}(0 \%)$ & $\mathrm{O}(\mathrm{O} \%)$ & 1.44 & 0.50 \\
\hline 6. & $\begin{array}{l}\text { It raises investors' confidence and } \\
\text { customers' loyalty }\end{array}$ & $37(74 \%)$ & $13(26 \%)$ & $\mathrm{O}(\mathrm{O} \%)$ & $\mathrm{O}(0 \%)$ & $\mathrm{O}(0 \%)$ & 1.26 & 0.44 \\
\hline 7. & $\begin{array}{l}\text { It raises public interest in the company's } \\
\text { activities }\end{array}$ & $38(76 \%)$ & $12(24 \%)$ & $\mathrm{O}(0 \%)$ & $\mathrm{O}(0 \%)$ & $\mathrm{O}(\mathrm{O} \%)$ & 1.24 & 0.43 \\
\hline 8. & $\begin{array}{l}\text { It improves public goodwill towards the } \\
\text { company }\end{array}$ & $41(82 \%)$ & $9(18 \%)$ & $\mathrm{O}(0 \%)$ & $\mathrm{O}(0 \%)$ & $\mathrm{O}(\mathrm{O} \%)$ & 1.18 & 0.38 \\
\hline 9. & $\begin{array}{l}\text { It facilitates the overall performance of } \\
\text { the company }\end{array}$ & $25(50 \%)$ & $15(30 \%)$ & $\mathrm{O}(\mathrm{O} \%)$ & $\begin{array}{c}10 \\
(20 \%)\end{array}$ & $\mathrm{O}(\mathrm{O} \%)$ & 1.50 & 0.50 \\
\hline 10. & $\begin{array}{l}\text { It leads to improved sales and increased } \\
\text { profits }\end{array}$ & $40(80 \%)$ & $10(20 \%)$ & $\mathrm{O}(\mathrm{O} \%)$ & $\mathrm{O}(0 \%)$ & $\mathrm{O}(\mathrm{O} \%)$ & 1.20 & 0.40 \\
\hline 11. & It aids organizational growth & $35(70 \%)$ & $15(30 \%)$ & $\mathrm{O}(0 \%)$ & $\mathrm{O}(0 \%)$ & $0(0 \%)$ & 1.30 & 0.46 \\
\hline 12. & It attracts positive media attention & $20(40 \%)$ & $18(36 \%)$ & $2(4 \%)$ & $8(16 \%)$ & $2(4 \%)$ & 2.08 & 1.20 \\
\hline 13. & It increases our market share & $31(62 \%)$ & $17(34 \%)$ & $2(4 \%)$ & $\mathrm{O}(\mathrm{O} \%)$ & $\mathrm{O}(0 \%)$ & 1.42 & 0.57 \\
\hline 14. & It makes access to finance easier & $17(34 \%)$ & $23(46 \%)$ & $3(6 \%)$ & $5(10 \%)$ & $2(4 \%)$ & 2.04 & 1.08 \\
\hline 15. & It eases/reduces regulatory burden & $12(24 \%)$ & $19(38 \%)$ & $6(12 \%)$ & $9(18 \%)$ & $4(8 \%)$ & 2.48 & 1.26 \\
\hline
\end{tabular}

Source: Fieldwork (2020).

\subsubsection{Challenges/Problems Faced in the Practice of CSR}

Table 4 presents the responses of the respondents on the challenges MTN faces in the course of practising CSR. $28 \%, 36 \%, 4 \%, 8 \%$ and $4 \%$ of the respondents strongly agreed, agreed, were undecided, disagreed and strongly disagreed respectively that CSR increases in the cost of doing business. Since the percentage that agrees to this exceeds those that disagreed or are undecided, then it is apparent that CSR actually increases in the cost of doing business. Likewise, $46 \%, 38 \%, 12 \%$ and $4 \%$ of the respondents strongly agreed, agreed, disagreed and strongly disagreed respectively that CSR lowers the profitability of the company. The percentage of those that agreed exceed those that disagreed, thus, CSR actually lowers the profitability of the company. In addition while $22 \%$ and $58 \%$ of the respondents strongly agreed and agreed respectively that lack of shareholders' commitment is a problem they encounter in the practise of CSR, $14 \%$ and $6 \%$ of the respondents strongly disagreed and disagreed respectively. Furthermore, $54 \%, 28 \%, 8 \%, 8 \%$ and $2 \%$ of the respondents strongly agreed, agreed, were undecided, disagreed and strongly disagreed respectively that the company's CSR is not recognized by society. Thus, lack of recognition of the company's CSR is a major problem faced by MTN in Ibadan. Moreover, $18 \%, 26 \%, 4 \%, 20 \%$ and $32 \%$ of the respondents strongly agreed, agreed, were undecided, disagreed and strongly disagreed respectively that lack of organizational commitment is a challenge face in the practice of CSR. Given that the percentage of those who disagreed exceeds that of those who agreed, it can be said that MTN is committed to practising CSR in Ibadan and that lack of organizational commitment is not a challenge they face. Lastly, $4 \%, 22 \%, 16 \%$ and $58 \%$ of the respondents strongly agreed, agreed, disagreed and strongly disagreed respectively that MTN lacks of CSR strategy. Given that the percentage of those who disagreed exceeds that of those who agreed, it can be said that MTN does not lack CSR strategy.

Table-4.Challenges/problems faced in the practice of CSR

\begin{tabular}{l|l|c|c|c|c|c|c|c}
\hline No. & $\begin{array}{l}\text { Challenges/Problems Faced in the } \\
\text { Practice of CSR }\end{array}$ & SA & A & U & D & SD & Mean & Std. Dev. \\
\hline 1. & Increase in the cost of doing business & $14(28 \%)$ & $18(36 \%)$ & $2(4 \%)$ & $4(8 \%)$ & $2(4 \%)$ & 2.04 & 1.01 \\
\hline 2. & Low profitability of the company & $23(46 \%)$ & $19(38 \%)$ & $0(0 \%)$ & $6(12 \%)$ & $2(4 \%)$ & 1.74 & 0.82 \\
\hline 3. & Lack of shareholders' commitment & $11(22 \%)$ & $29(58 \%)$ & $0(0 \%)$ & $7(14 \%)$ & $3(6 \%)$ & 2.04 & 0.78 \\
\hline 4. & $\begin{array}{l}\text { The company's CSR is not recognized } \\
\text { by society }\end{array}$ & $27(54 \%)$ & $14(28 \%)$ & $4(8 \%)$ & $4(8 \%)$ & $1(2 \%)$ & 1.76 & 1.04 \\
\hline 5. & Lack of organizational commitment & $9(18 \%)$ & $13(26 \%)$ & $2(4 \%)$ & $10(20 \%)$ & $16(32 \%)$ & 2.66 & 1.55 \\
\hline 6. & Lack of CSR strategy & $2(4 \%)$ & $11(22 \%)$ & $0(0 \%)$ & $8(16 \%)$ & $29(58 \%)$ & 1.86 & 1.26 \\
\hline
\end{tabular}

Source: Fieldwork (2020). 


\section{$H_{I:}$ CSR has significant impact on performance of MTN, Ibadan}

The correlation coefficient of approximately 0.88 indicates a strong positive relationship between MTN's Corporate Social Responsibility (CSR) and her firm performance in Ibadan see Table 5. Further, the R-Squared value shows that about 76.8 percent of the variation in MTN Ibadan performance is explained by her CSR activities. In other words, CSR activities predict about 76.8 percent variability in MTN Ibadan's performance. The remaining 23.2 per cent is accounted for by other variables not specified in the model.

On the other hand, Table 6 shows that probability of the F-statistic is significant at all levels of significance, implying that the null hypothesis will be rejected while the alternative hypothesis will be accepted. This indicates that the performance of MTN Service Centres in Ibadan is influenced by the extent to which it carries out corporate social responsibilities.

Table-5.Model Summary:

\begin{tabular}{c|c|c|c|c}
\hline Model & $\mathbf{R}$ & R-Square & Adjusted R Square & Std. Error of the Estimate \\
\hline 1 & $.876^{\mathrm{a}}$ & .768 & .765 & 1.05152 \\
\hline
\end{tabular}

Table-6.Analysis of Variance (ANOVA)

\begin{tabular}{l|c|c|c|c|c|c}
\hline \multicolumn{2}{c|}{ Model } & Sum of Squares & Df & Mean Square & F & Sig. \\
\hline \multirow{3}{*}{} & Regression & 329.227 & 1 & 329.227 & 297.758 & $.000^{\mathrm{b}}$ \\
\cline { 2 - 7 } & Residual & 99.512 & 90 & 1.106 & & \\
\cline { 2 - 7 } & Total & 428.739 & 91 & & & \\
\hline Note:
\end{tabular}

a. Dependent Variable: Firm Performance.

b. Predictors: (Constant), CSR.

The regression result is presented in Table 7 which shows the magnitude of CSR on firm performance. Specifically, it indicates that CSR has a significant positive relationship with firm performance such that when MTN increases its CSR activities by one unit, firm performance will improve by about 0.5 unit. This implies that CSR plays a very pivotal role in the firm performance of MTN Service Centres in Ibadan and that CSR is a major determinant of MTN Ibadan's performance. This result supports the findings of Adebisi and Akinmadelo (2014); Wael (2014); Boafo and Kokuma (2016) and Olaroyeke and Nasieku (2015). The foregoing shows that it is imperative for the management of MTN Service Centres in Ibadan to take CSR activities control very seriously because it is a key determinant of her organizational performance. CSR is so critical that the management of MTN Service Centres in Ibadan should endeavour to deliberately invest in CSR activities so as to increase their performance, profitability, impact and fame in the neighbourhood wherein they operate.

\begin{tabular}{|c|c|c|c|c|c|}
\hline \multirow[t]{2}{*}{ Model } & & & Standardized Coefficients & \multirow[t]{2}{*}{$\mathbf{T}$} & \multirow[t]{2}{*}{ Sig. } \\
\hline & B & Std. Error & Beta & & \\
\hline (Constant) & .944 & .466 & & 2.025 & 0.46 \\
\hline CSR & .490 & .028 & .876 & 17.256 & .000 \\
\hline
\end{tabular}

\section{Conclusion and Policy Recommendations}

This study evaluated the impact of corporate social responsibility on firm performance using MTN Service centres in Ibadan as case study. Tables and simple percentages were used for the analysis of the data collected through the administration of questionnaires while the correlation coefficient and analysis of variance were employed as the analytical tool for this study. The results showed that all the MTN service centres in Ibadan participates or carries out CSR even though they highlighted a few challenges they face in the course of engaging in CSR. However, it was also found that several benefits accrue to MTN in Ibadan as a result of carrying out CSR activities. These benefits include: improvement in company' reputation (goodwill), improved sales and profits, ease in regulatory burdens, increase in investors' confidence and customers' loyalty, and attraction of positive media attention, among others. Hence, it can be said that the benefits MTN Ibadan gets from engaging in CSR activities far outweighs the challenges they face implementing them. Furthermore, the correlation coefficient revealed a strong positive relationship between MTN's Corporate Social Responsibility (CSR) and her organizational performance in Ibadan. Similarly, the regression result showed a significant positive relationship between CSR and firm performance which indicates that CSR plays a pivotal role in the performance of MTN Service Centres in Ibadan. Thus, this study concludes that CSR is a major determinant of firm performance. Intuitively, the profitability, corporate image, and sales, of MTN thrive on account of the CSR activities it carries out in its local (host) community and beyond. In other words, the success in organizational performance MTN has recorded so far in Ibadan can be linked to the CSR activities it carries out in its host community and beyond. Based on foregoing, it is important that the management of MTN Nigeria endeavour to engage in more CSR activities to meet the peculiar needs of their immediate environment and the government should put appropriate measures in place to ensure that CSR is carried out by corporate organizations so as to complement the efforts of the government towards growth and development of Nigeria, and appropriate punishments should be mete on defaulters.

\section{References}

Adebisi, S. A., \& Akinmadelo, T. (2014). Building winning strategy for competitive performance through corporate social responsibility: An X-Ray Of Mtn Nigeria. Management Strategies Journal, Constantin Brancoveanu University, 24(2), 48-61.

Adeyanju, O. D. (2012). An assessment of the impact of corporate social responsibility on Nigerian society: The examples of banking and communication industries. Universal Journal of Marketing and Business Research, 1(1), o17-043.

Akinleye, G. T., \& Adedayo, T. F. (2017). Impact of corporate social responsibility on the profitability of multinational companies in Nigeria. Global Journal of Management and Business Research: Accounting and Auditing, 17(3), 27-35. 
Amposah-Tawiah, K., \& Dartey-Baah, K. (2011). Corporate social responsibility in ghana. International Journal of Business and Social Science, 2(17), 107-112.

Boafo, N. D., \& Kokuma, D. A. (2016). The impact of corporate social responsibility on organisational performance: A case study of vodafone Ghana limited. European Journal of Business and Management, 8(22), 46-57.

Brown, T. J., \& Dacin, P. A. (1997). The company and the product: Corporate associations and consumer product responses. Journal of Marketing, 61(1), 68-84.Available at: https://doi.org/10.2307/1252190.

Diffey, G. (2007). CSR, a risky business-risk management and CSR. Retrieved from: https://www.fundacionseres.org/lists/informes/attachments/1109/csr-a-risky-business.pdf.

Elizaveta, G. (2010). Corporate social responsibility in the context of youth summit. Retrieved from: http://www.generationeurope.eu/forum/category/idea-incubator.

Freeman, R. E., \& Phillips, R. A. (2002). Stakeholders theory: A libertarian defence. Business Ethics and Quarterly, 12(3), 331-349.

Gbam, B., \& Dedi, H. M. (2017). Effects of corporate social responsibility on organizational performance: A study of Nigeria's telecommunication industry. Journal of Research in Humanities and Social Science, 5(5), 55-63.

Kanwal, M., Khanam, F., Nasreen, S., \& Hameed, S. (2013). Impact of corporate social responsibility on the firm's financial performance. IOSR Journal of Business and Management, 14(5), 67-74.

Korkchi, S., \& Rombaut, A. (2007). Corporate social responsibility: A case study on private and public corporations in Sweden. Bachelor Thesis, Institution for Business Administration and Economics, South Stockholm University- Södertörn School of Economics and Business Studies. Retrieved from Retrieved from http://www.diva-portal.org/smash/get/diva2:16710/fulltexto1

Kotler, P., \& Lee, N. (2005). Corporate social responsibility: Doing the most good for your company and your cause. Hoboken, New Jersey: John Wiley \& Sons, Inc.

Lee, M. P. (2008). Review of the theories of corporate social responsibility: Its evolutionary path and road ahead. International Journal of Management Reviews, $10(1)$, 53-73.Available at: https://doi.org/10.1111/j.1468-2370.2007.00226.x.

Mirfazli, E. (2008). Evaluate corporate social responsibility disclosure annual Report companies in multifarious group of industry members of Jakarta Stock Exchange, Indonesia. Social Responsibility Journal, 4(3), 11-30.

Mujahid, M., \& Abdullah, A. (2014). Impact of corporate social responsibility on firms financial performance and shareholders wealth. European Journal of Business and Management, 6(31), 181-187.

Nguyen, H. T., Hoang, T. G., \& Luu, H. (2019). Corporate social responsibility in vietnam: Opportunities and innovation experienced by multinational corporation subsidiaries. Social Responsibility Journal, 16(6), 771-792.Available at: https://doi.org/10.1108/srj-022019-0082

Nnamani, J. N., Onyekwelu, U. L., \& Ugwu, O. K. (2017). Effect of sustainability accounting and reporting on financial performance of firms in Nigeria Brewery Sector. European Journal of Business and Innovation Research, 5(1), 1-15.

Nsikan, J. E., Umoh, V. A., \& Bariate, M. (2015). Corporate social responsibility and mobile telecommunication competitiveness in Nigeria: The Case of MTN Nigeria. American Journal of Industrial and Business Management, 5(8), 527-537.

Ogunsanwo, O. F., \& Ajayi, I. E. (2018). Corporate social responsibility on the performance of private telecommunication in Nigeria. Canadian Social Science, 14(8), 45-54.

Ohiokha, F. I., Odion, O. A., \& Akhalumeh, P. B. (2016). Corporate social responsibility and corporate financial performance: The Nigerian experience. International Journal of Accounting Research, 2(10), 34-43.

Oladimeji, M. S., Adebayo, L. A., \& Ogunshola, B. G. (2017). Effect of corporate social responsibility on customers' loyalty and retention. Journal of Management Research, 9(1), 1-7.

Olaroyeke, R. T., \& Nasieku, T. (2015). Effect of corporate social responsibility on performance of manufacturing companies in Nigeria International Journal of Current Advanced Research, 4(8), 228-233.

Secchi, D. (2007). Utilitarian, managerial and rational theories of corporate social responsibility. International Journal of Management Review, 9(4), 347-373.Available at: https://doi.org/10.1111/j.1468-2370.2007.00215.x.

Smith, N. C. (2003). Corporate social responsibility: Whether or how? California Management Review, 45(4), 52-76.Available at: https://doi.org/10.2307/41166188.

Tapang, A. T., \& Bassey, E. B. (2017). Effect of corporate social responsibility performance on stakeholder's perception of telecommunication companies In Nigeria A Study of MTN, Globalcom \& Etisalat. IOSR Journal of Business and Management, 19(6), 39-55.Available at: https://doi.org/10.9790/487x-1906053955.

Tsoutsoura, M. (2004). Corporate social responsibility and financial performance. Hass School Business, University of California at Berkeley, Applied Financial Report.

Tuodolo, F. (2009). Corporate social responsibility: Between civil society and the oil Industry in the developing world. ACME: An International Journal for Critical Geographies, 8(3), 530-541.

Wael, J. A. (2014). The effect of corporate social responsibility toward the local community and employees on orange telecom company profit. International Journal of Humanities and Social Science, 4(13), 198-203.

Citation: Joshua Adeyemi Ogunjimi (2020). Corporate Social Responsibilities and Firm Performance. Asian Business Research Journal, 5: 55-61.

History:

Received: 28 October 2020

Revised: 20 November 2020

Accepted: 4. December 2020

Accepted: 4 December 2020

Published: 18 December 2020

Licensed: This work is
Attribution 3.0 License (cc)

Publisher: Eastern Centre of Science and Education

Eastern Centre of Science and Education is not responsible or answerable for any loss, damage or liability, etc. caused in relation to/arising out of the use of the content. Any queries should be directed to the corresponding author of the article.
Funding: This study received no specific financial support.

Competing Interests: The author declares that there are no conflicts of interests regarding the publication of this paper.

Transparency: The author confirms that the manuscript is an honest, accurate, and transparent account of the study was reported; that no vital features of the study have been omitted; and that any discrepancies from the study as planned have been explained.

Ethical: This study follows all ethical practices during writing. 